\title{
Predicting the outcome in children with head trauma: comparison of FOUR score and Glasgow Coma Scale
}

\author{
Kafa travması ile acil servise getirilen çocuklarda sonuç öngörüsü: \\ FOUR skoru ve Glaskow Koma Skalası karşılaştırılması
}

\author{
Fatih BÜYÜKCAM, Ural KAYA, Muhamed Evvah KARAKILIÇ, Umut Yücel ÇAVUŞ, \\ Feruza TURAN SÖNMEZ, Öner ODABAŞ
}

\section{BACKGROUND}

Because of the limitations of the Glasgow Coma Scale (GCS), many scoring systems have emerged and been compared with GCS. Herein, we investigated whether the Full Outline of Unresponsiveness (FOUR) score is better than GCS in predicting morbidity and mortality in children with head trauma.

\section{METHODS}

Patients 2-17 years of age who admitted to the emergency department with head trauma and presented with altered level of consciousness were included in this study. Inhospital mortality, hospitalization of more than three days, and Glasgow Outcome Score (GOS) at discharge and after three months were used as the primary outcome measures.

\section{RESULTS}

A total of 100 children were included in the study. The median age was 6 years, and $69 \%$ were male. The in-hospital mortality rate was $10 \%$. The cut-off values for predicting in-hospital mortality were 9 for FOUR score and 7 for GCS. Area under the curve (AUC) values in predicting inhospital mortality, poor GOS (score of 1-3) at discharge, and poor GOS after three months were similar for GCS and FOUR score.

\section{CONCLUSION}

FOUR score provides no significant advantage over GCS in predicting morbidity and mortality in children with head trauma.

Key Words: Altered consciousness; coma scales; FOUR score; Glasgow coma scale; pediatric trauma.

\section{AMAÇ}

Glasgow Koma Skalası'nın (GKS) kısıtlılıkları bulunduğundan birçok değişik skorlama sistemleri GKS ile karş1laştırılmıştır. Bu çalışmada, acil servise kafa travması ile getirilen çocuk hastalarda Full Outline of Unresponsiveness (FOUR) skorunun GKS skorundan daha iyi morbidite ve mortalite öngörüsünün olup olmadığı araştırıldı.

\section{GEREC VE YÖNTEM}

İki ile on yedi yaş arasında bilinç değişikliği ile acil servise getirilen kafa travmalı çocuk hastalar çalışmaya alındı. Hastane içi mortalite, üç günden fazla hastanede yatış, taburculukta ve üç ay sonraki Glasgow Sonuç Skoru (GOS) değerleri primer sonuç ölçümleri olarak alındı.

\section{BULGULAR}

Toplamda 100 hasta çalışmaya alındı. Hastaların ortanca yaşı 6 ve \%69'u erkekti. Hastane içi mortalite oranı \%10’du. Hastane içi mortalite öngörüsünde FOUR skoru için eşik değer 9, GKS için 7 idi. GKS ve FOUR skoru için eğri altında kalan alan; hastane içi mortalite, taburculukta ve üç ay sonraki kötü GOS (skor 1-3 arasında) öngörüsünde benzer değerlere sahipti.

\section{SONUÇ}

FOUR skorunun kafa travmalı çocuk hastalarda, morbidite ve mortalite öngörüsünde GKS'ye göre belirgin bir avantaj sağlamadığ1 gözlemlendi.

Anahtar Sözcükler: Bilinç değişikliği; koma skorlaması; FOUR skoru; Glasgow koma skalası; çocuk travma. 
Glasgow Coma Scale (GCS) is the most widely used scoring system for the evaluation of disorder of consciousness. It was developed by Teasdale and Jennett in 1974. ${ }^{[1]}$ This coma scale is an objective evaluation of patients with the provision of scoring and it provides for the building of a common language among health professionals. The modified GCS (Table 1) is used for infants and young children in order to obtain the most accurate score. ${ }^{[2]}$ GCS provides a prediction about morbidity and mortality after head injury, but there are some limitations to the use of this scale. One of these limitations is the lack of consistent interobserver agreement. $^{[3]}$ Additionally, intubated patients and patients with speech disorders cannot be evaluated by verbal response. Because of the limitations of the GCS, especially in the verbal evaluation, many scoring systems have emerged and been compared with GCS.

The Full Outline of Unresponsiveness (FOUR) score is a new scoring system that has been developed to overcome the specific limitations of GCS, especi- ally in verbal response. It was developed by Wijdicks et al., ${ }^{[4]}$ and further validations of this scale were done by other researches. ${ }^{[5-10]}$ It is composed of eye, motor, brainstem, and respiration responses with a scale of $0-4(0=$ worst, $4=$ best $)$ as demonstrated in Table 1 . The FOUR score specifically distinguishes certain unconsciousness states, provides important details such as brainstem reflexes, and includes the minimal necessities of neurological testing in altered mental status. ${ }^{[4]} \mathrm{It}$ also recognizes uncal herniation, a locked-in syndrome, and the beginning of a vegetative state, which the GCS does not do. ${ }^{[11]}$

Wijdicks et al. ${ }^{[4]}$ noted that a better evaluation of intubated patients has been provided by this new coma scale. They also indicated that the FOUR score could be remembered and carried out easily since all the scores are within the same $0-4$ range. ${ }^{[4]}$ Brainstem reflexes and respiratory pattern also provide an objective evaluation rather than verbal response. ${ }^{[4]}$ For those under the age of five, a modified GCS is used because of the limitations of the verbal component of the GCS. ${ }^{[2,12]}$

Table 1. FOUR Score and Glasgow Coma Scale

\begin{tabular}{|c|c|}
\hline Full Outline of Unresponsiveness Score* & Modified Glasgow Coma Scale Score for Children ${ }^{* *}$ \\
\hline Eye response & Eye response \\
\hline $4=$ Eyelids open or opened, tracking, or & $4=\quad$ Eyes open spontaneously \\
\hline blinking to command & Eye opening to verbal command \\
\hline $3=$ Eyelids open but not tracking & Eye opening to pain \\
\hline $2=$ Eyelids closed but open to loud voice & No response to pain \\
\hline $1=$ Eyelids closed but open to pain & Motor response \\
\hline $0=$ Eyelids remain closed with pain & $6=$ Obeys commands \\
\hline Motor response & $5=\quad$ Localizes pain \\
\hline $4=$ Thumbs-up, fist, or peace sign & Flexion withdrawal \\
\hline $3=$ Localizing to pain & Abnormal flexion (decorticate) \\
\hline $2=$ Flexion response to pain & Extension (decerebrate) \\
\hline $1=$ Extension response to pain & $1=\quad$ No response \\
\hline $0=$ No response to pain or generalized myoclonus status & Verbal Response (2-5 years) \\
\hline Brainstem reflexes & $5=\quad$ Appropriate words \\
\hline $4=$ Pupil and corneal reflexes present & Inappropriate words \\
\hline $3=$ One pupil wide and fixed & Screams \\
\hline $2=$ Pupil or corneal reflexes absent & Grunts \\
\hline $1=$ Pupil and corneal reflexes absent & $1=\quad$ No response \\
\hline $0=$ Absent pupil, corneal, and cough reflex & Verbal response ( $>5$ years) \\
\hline Respiration & $5=\quad$ Oriented \\
\hline $4=$ Not intubated, regular breathing pattern & Confused \\
\hline $3=$ Not intubated, Cheyne-Stokes breathing pattern & Inappropriate words \\
\hline $2=$ Not intubated, irregular breathing & Incomprehensible sounds \\
\hline $1=$ Breathes above ventilator rate & No response to pain \\
\hline $0=$ Breathes at ventilator rate or apnea & \\
\hline
\end{tabular}

"Wijdicks EF, Bamlet WR, Maramattom BV, et al. Validation of a new coma scale: the FOUR score. Ann Neurol 2005;58(4):585-93 ** Marcoux, KK. Management of increased intracranial pressure in the critically ill child with an acute neurological injury. AACN Clin Issues 2005;16(2): 212-31; quiz 270-1.

Note: Verbal response of infants and non-verbal children was not related with our study and thus not included in this table. 
Validation of the FOUR score in different languages and patient types was done over time. ${ }^{[4,5,9,13-17]}$ In all these studies, it was indicated that the FOUR score has similar inter-rater reliability values to those of the GCS. Orken et al. ${ }^{[18]}$ searched the reliability of the Turkish version of the FOUR score in a neurological intensive care unit, and showed that the interobserver reliability was excellent for both FOUR score and GCS; additionally, the outcome prediction of the FOUR score was as effective as that of the GCS.

A comparison of FOUR score with GCS in predicting morbidity and mortality was performed by some researches in adult populations, ${ }^{[19-22]}$ and a few researches were performed in the pediatric population. ${ }^{[7]}$ In this study, we investigated whether the FOUR score is better than the GCS in predicting morbidity and mortality in children aged 2-17 years presenting to the emergency department (ED) with head trauma.

\section{MATERIALS AND METHODS}

This prospective observational study was performed in a tertiary care state hospital ED with a total admission of 134,287 from March to August 2010. 19,818 of them were aged 2-17 years. The study protocol was approved by the local ethics committee.

Patients admitted to the ED with head trauma aged between 2-17 who presented with severe head or facial bleeding, bleeding or fluid leakage from the nose or ears, severe headache, change in level of consciousness for more than a few seconds, black-and-blue discoloration below the eyes or behind the ears, cessation of breathing, confusion, loss of balance, weakness or an inability to use an arm or leg, unequal pupil size, slurred speech, seizures, persistent crying, refusal to eat, bulging in the soft spot on the front of the head (infants), or vomiting after head trauma were included in the study. Patients that initially had altered consciousness but had returned to normal baseline prior to arriving in the ED were also included in the study. Patients with no history of changes in consciousness; who were intubated before admission to the hospital (intubated patients cannot be evaluated with the verbal component of GCS) or had been administered sedative or paralytic agents before admission; who demonstrated evidence or history of intoxication; and those with known speech, vision, hearing, or motor impairments were excluded from the study.

Before starting the study, all attending physicians and residents in a five-year residency program were trained on the FOUR score, GCS modified for children and Glasgow Outcome Score (GOS) to standardize physicians' definitions. Written definitions of the three scales were included in the study form. Written informed consent was provided by the parents of the patients, and they were informed that they would be contacted three months after discharge. The FOUR score and GCS of the patients were recorded before any medical procedure. The primary outcome measures were hospitalization of more than three days, in-hospital mortality, morbidity at discharge, and morbidity after three months using GOS. Poor outcome was defined as a GOS of 1-3. The enrollment form included age and sex of the patients, FOUR score, GCS, hospital mortality, and GOS at discharge and after three months.

FOUR score and modified GCS are explained in Table 1 . The GOS can be defined as: $5=$ good recovery, resumption of normal life despite minor deficits; $4=$ moderate disability, disabled but independent, can work in sheltered setting; $3=$ severe disability, conscious but disabled, dependent for daily support; 2 = persistent disability, minimal responsiveness; $1=$ death.

All statistical analyses were performed using the Statistical Package for the Social Sciences (SPSS) 15.0 for Windows (SPSS Inc., Chicago, IL, USA). Continuous variables were expressed by mean \pm standard deviation, ordinal variables as median and minimum-maximum, and frequent variables as rates. Correlation between outcome measures and coma scales was determined by Spearman correlation coefficient. The predictive value of GCS and FOUR score in predicting primary outcome measures was established by receiver operating characteristic (ROC) curve by calculating area under the curve (AUC) values by $95 \%$ confidence intervals (CI). Youden Index was used to calculate the cut-off values in predicting a poor outcome. All hypotheses were constructed as two-tailed, and $\mathrm{p} \leq 0.05$ was considered significant.

\section{RESULTS}

A total of 106 patients were evaluated in the study. Six were excluded because they could not be reached for telephone follow-up at the end of the three months. The remaining 100 patients comprised the study population. The median age was 6 years (mean age: $7.06 \pm 4.42$ ) and $69 \%$ of them were male. The distribution GCS and FOUR scores is shown in Figures 1 and 2, respectively. Ten of the patients $(10 \%)$ died in the hospital; there were no other deaths after discharge at the three-month follow-up. $14 \%$ of patients had poor outcomes according to the GOS (GOS=1-3). Moderate correlations were observed between GCS and FOUR scores and in-hospital mortality $(\mathrm{r}=-0.489$ for GCS, $r=-0.512$ for FOUR score; $p=0.000)$, GOS at discharge $(\mathrm{r}=-0.511$ for GCS, $\mathrm{r}=-0.510$ for FOUR score; $\mathrm{p}=0.000)$ and GOS after three months $(\mathrm{r}=-0.489$ for GCS, $r=-0.512$ for FOUR score; $\mathrm{p}=0.000$ ); a poor correlation was observed between hospitalization duration and both GCS and FOUR score ( $\mathrm{r}=-0.334$ for GCS, $\mathrm{r}=-0.316$ for FOUR score; $\mathrm{p}=0.000$ ). 
Table 2. Receiving operating characteristic curve analyses in predicting in-hospital mortality, hospitalization duration and poor outcome for GCS, FOUR score, and subunits of the two scales

\begin{tabular}{|c|c|c|c|c|}
\hline Variable & AUC (95\% CI) & $\begin{array}{l}\text { Hospitalization } \\
\qquad>3 \text { days } \\
\text { AUC }(95 \% \mathrm{CI})\end{array}$ & $\begin{array}{l}\text { Poor GOS }(1-3) \\
\text { at discharge } \\
\text { AUC }(95 \% \mathrm{CI})\end{array}$ & $\begin{array}{c}\text { Poor GOS }(1-3) \text { after } \\
3 \text { months } \\
\text { AUC }(95 \% \mathrm{CI})\end{array}$ \\
\hline Total GCS & $0.965(0.909-1.021)$ & $0.726(0.607-0.845)$ & $0.884(0.783-0.986)$ & $0.965(0.909-1.021)$ \\
\hline Eye & $0.949(0.900-0.999)$ & $0.656(0.527-0.786)$ & $0.868(0.767-0.968)$ & $0.949(0.900-0.999)$ \\
\hline Motor & $0.961(0.900-1.022)$ & $0.688(0.571-0.805)$ & $0.882(0.765-0.999)$ & $0.961(0.900-1.022)$ \\
\hline Verbal & $0.931(0.846-1.016)$ & $0.759(0.650-0.868)$ & $0.863(0.756-0.969)$ & $0.931(0.846-1.016)$ \\
\hline Total FOUR Score & $0.975(0.931-1.019)$ & $0.716(0.595-0.837)$ & $0.870(0.746-0.993)$ & $0.975(0.931-1.019)$ \\
\hline Eye & $0.933(0.874-0.993)$ & $0.700(0.581-0.819)$ & $0.845(0.725-0.964)$ & $0.933(0.874-0.993)$ \\
\hline Motor & $0.961(0.899-1.022)$ & $0.686(0.568-0.803)$ & $0.880(0.763-0.998)$ & $0.961(0.899-1.022)$ \\
\hline Brainstem reflexes & $0.896(0.745-1.046)$ & $0.567(0.438-0.695)$ & $0.777(0.610-0.945)$ & $0.896(0.745-1.046)$ \\
\hline Respiration & $0.932(0.821-1.044)$ & $0.617(0.488-0.745)$ & $0.837(0.692-0.982)$ & $0.932(0.821-1.044)$ \\
\hline
\end{tabular}

"AUC: Area under the curve; CI: Confidence interval; FOUR: Full outline of unresponsiveness; GCS: Glasgow coma scale; GOS: Glasgow outcome score.

AUC values in predicting in-hospital mortality and poor GOS after three months were 0.965 for GCS $(\mathrm{p}=0.0001,95 \%$ CI: $0.909-1.021)$ and 0.975 for FOUR score ( $\mathrm{p}=0.0001,95 \% \mathrm{CI}$ : 0.931-1.019). AUC values in predicting in-hospital mortality, hospitalization of more than 3 days, and poor outcome for GOS at discharge and after three months are listed in Table 2. The cut-off values in predicting in-hospital mortality were 9 [positive likelihood ratio $=20$, Odds ratio (OR) 69\% (2.2)] for FOUR score and 7 for GCS [positive likelihood ratio $=41$, OR $82 \%$ (4.6)].

\section{DISCUSSION}

In our study, Spearman correlation between hospitalization duration and GCS and FOUR score was poor, but moderate correlations were observed between both GCS and FOUR score and the GOS score at discharge, GOS score after three months and in-hospital mortality. Eken et al. ${ }^{[19]}$ reported a moderate correlation between the Modified Rankin Score

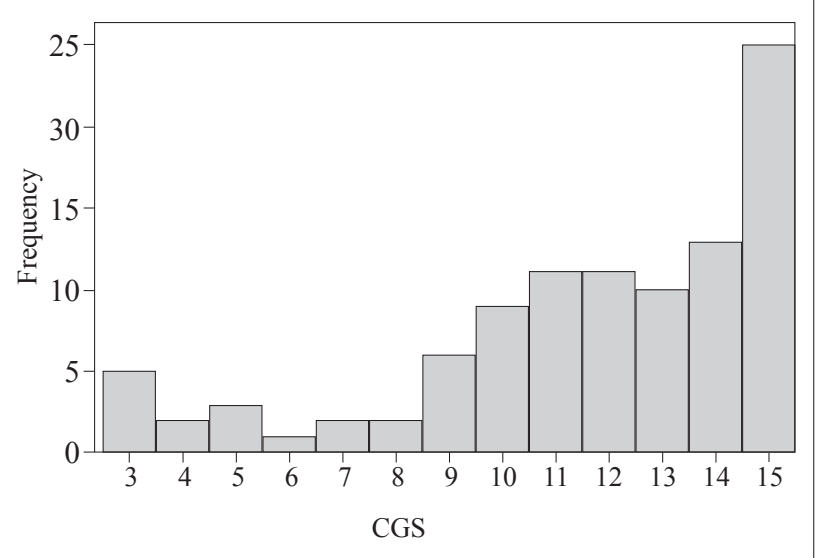

Fig. 1. Frequency of Glasgow Coma Scale (GCS) scores (range: 3-15) among the study population.
(MRS) at the end of the three months and both GCS and FOUR score.

Wijdics et al. ${ }^{[4]}$ reported that the verbal component of GCS was similar to the brainstem reflexes and respiratory component of FOUR score in predicting in-hospital mortality (OR: GCS-Verbal: 0.65, FOUR-Brainstem: 0.64, FOUR-Respiratory pattern: 0.74; CI: 95\%). Eken et al. ${ }^{[19]}$ reported that the verbal component of GCS was better than the brainstem reflexes and respiratory component of FOUR score in predicting in-hospital mortality (AUC values: GCS-Verbal: 0.705, FOUR-Brainstem reflexes: 0.598, and FOUR-Respiratory pattern: 0.585; CI: 95\%). In our study, the verbal component of GCS was similar to the respiratory pattern of FOUR score, but it was slightly superior to the brainstem reflexes component of the FOUR score in predicting in-hospital mortality (AUC values: GCS-Verbal: 0.931, FOUR-Brainstem reflexes: 0.896, FOUR-Respiratory pattern: 0.932; CI: $95 \%)$. The results of these three studies show that the

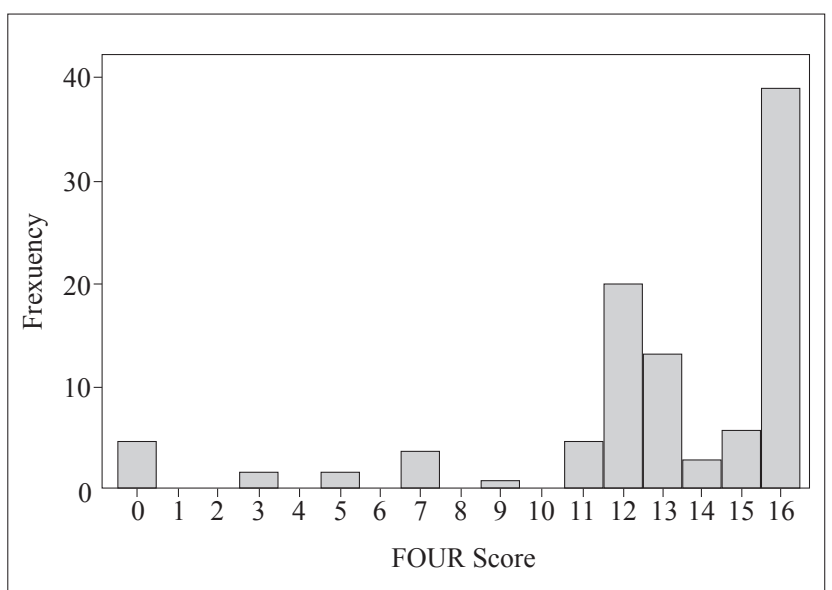

Fig. 2. Frequency of Full Outline of Unresponsiveness (FOUR) scores (range: 0-16) among the study population. 
brainstem reflexes and respiratory pattern evaluation in FOUR score have no particular advantage over the verbal component of the GCS in predicting in-hospital mortality. We also showed in our study that the verbal component of the GCS has a good predictive value in predicting in-hospital mortality. Rutlage et al. ${ }^{[23]}$ reported that the eye and motor component of the GCS was sufficient in predicting poor outcome if the verbal component of GCS cannot be evaluated.

Eken et al. ${ }^{[19]}$ reported that the FOUR score has slightly better but not significantly different AUC values when compared to the GCS in all outcome measures. In our study, in predicting hospitalization of more than three days and poor outcome at discharge and after three months, the total GCS value was better than the total FOUR score, and further, in predicting hospital mortality, the total FOUR score was slightly better than the total GCS, but these differences were not significant (Table 2).

In conclusion, the FOUR score was developed to overcome the limitations of the GCS, but it does not appear to provide a significant benefit. The GCS has been the most commonly used scale for an extended period, so it would be difficult to employ another coma scale in its place, unless an alternative scale is shown to have significant advantages in predicting a poor outcome. Further studies of coma scales should be conducted among children.

Among the limitations of this study, the study population consisted only of children with head trauma. The hospital in which the study was conducted is a primary trauma center for children; thus, we did not investigate the children with altered mental status without trauma. A comparison of the two scales on traumatic and nontraumatic children with altered mental status could be investigated in further studies. Further, the inter-rater reliability was not investigated in this study.

\section{REFERENCES}

1. Teasdale G, Jennett B. Assessment of coma and impaired consciousness. A practical scale. Lancet 1974;2:81-4.

2. Marcoux KK. Management of increased intracranial pressure in the critically ill child with an acute neurological injury. AACN Clin Issues 2005;16:212-31; quiz 270-1.

3. Gill MR, Reiley DG, Green SM. Interrater reliability of Glasgow Coma Scale scores in the emergency department. Ann Emerg Med 2004;43:215-23.

4. Wijdicks EF, Bamlet WR, Maramattom BV, Manno EM, McClelland RL. Validation of a new coma scale: The FOUR score. Ann Neurol 2005;58:585-93.

5. Wolf CA, Wijdicks EF, Bamlet WR, McClelland RL. Further validation of the FOUR score coma scale by intensive care nurses. Mayo Clin Proc 2007;82:435-8.

6. Akavipat P. Endorsement of the FOUR score for consciousness assessment in neurosurgical patients. Neurol Med Chir (Tokyo) 2009;49:565-71.

7. Cohen J. Interrater reliability and predictive validity of the
FOUR score coma scale in a pediatric population. $\mathrm{J}$ Neurosci Nurs 2009;41:261-9.

8. Fischer M, Rüegg S, Czaplinski A, Strohmeier M, Lehmann A, Tschan F, et al. Inter-rater reliability of the Full Outline of UnResponsiveness score and the Glasgow Coma Scale in critically ill patients: a prospective observational study. Crit Care 2010;14:R64.

9. Kevric J, Jelinek GA, Knott J, Weiland TJ. Validation of the Full Outline of Unresponsiveness (FOUR) Scale for conscious state in the emergency department: comparison against the Glasgow Coma Scale. Emerg Med J 2011;28:486-90.

10. Kornbluth J, Bhardwaj A. Evaluation of coma: a critical appraisal of popular scoring systems. Neurocrit Care 2011;14:134-43.

11. Wijdicks EF. Clinical scales for comatose patients: the Glasgow Coma Scale in historical context and the new FOUR Score. Rev Neurol Dis 2006;3:109-17.

12. Orliaguet GA, Meyer PG, Baugnon T. Management of critically ill children with traumatic brain injury. Paediatr Anaesth 2008;18:455-61.

13. Marcati E, Ricci S, Casalena A, Toni D, Carolei A, Sacco S. Validation of the Italian version of a new coma scale: the FOUR score. Intern Emerg Med 2012;7:145-52.

14. Idrovo L, Fuentes B, Medina J, Gabaldón L, Ruiz-Ares G, Abenza MJ, et al. Validation of the FOUR Score (Spanish Version) in acute stroke: an interobserver variability study. Eur Neurol 2010;63:364-9.

15. Weiss N, Mutlu G, Essardy F, Nacabal C, Sauves C, Bally $\mathrm{C}$, et al. The French version of the FOUR score: A new coma score. [Article in French] Rev Neurol (Paris) 2009;165:796802. [Abstract]

16. Stead LG, Wijdicks EF, Bhagra A, Kashyap R, Bellolio MF, Nash DL, et al. Validation of a new coma scale, the FOUR score, in the emergency department. Neurocrit Care 2009; 10:50-4.

17. Iyer VN, Mandrekar JN, Danielson RD, Zubkov AY, Elmer JL, Wijdicks EF. Validity of the FOUR score coma scale in the medical intensive care unit. Mayo Clin Proc 2009;84:694701 .

18. Orken DN, Sagduyu AK, Sirin H, Isikara CT, Gokce M, Sutlas N, et al. Reliability of the Turkish version of a new coma scale: FOUR Score. Trakya Universitesi Tip Fakultesi Dergisi 2010;27(1):28-31.

19. Eken C, Kartal M, Bacanli A, Eray O. Comparison of the Full Outline of Unresponsiveness Score Coma Scale and the Glasgow Coma Scale in an emergency setting population. Eur J Emerg Med 2009;16:29-36.

20. Köksal O, Ozdemir F, Bulut M, Aydin S, Almacioğlu ML, Ozgüç H. Comparison of trauma scoring systems for predicting mortality in firearm injuries. Ulus Travma Acil Cerrahi Derg 2009;15:559-64.

21. Ledoux D, Bruno M, Jonlet S, Choi P, Schnakers C, Damas F, et al. Full Outline of Unresponsiveness compared with Glasgow coma scale assessment and outcome prediction in coma. Critical Care 2009;13(Suppl 1):P107.

22. Akavipat P, Sookplung P, Kaewsingha P, Maunsaiyat P. Prediction of discharge outcome with the full outline of unresponsiveness (FOUR) score in neurosurgical patients. Acta Med Okayama 2011;65:205-10.

23. Rutledge R, Lentz CW, Fakhry S, Hunt J. Appropriate use of the Glasgow Coma Scale in intubated patients: a linear regression prediction of the Glasgow verbal score from the Glasgow eye and motor scores. J Trauma 1996;41:514-22. 